\title{
Liver glutathione depletion after preservation and reperfusion in human liver transplantation ${ }^{1}$
}

\author{
Depleção da glutationa hepática após preservação e reperfusão \\ no transplante de fígado em humanos
}

\begin{abstract}
Tomaz de Jesus Maria Grezzana Filho², Carlos Otávio Corso ${ }^{3}$, Maria Lúcia Zanotelli, Cláudio Augusto Marroni Ajácio Bandeira Mello Brandão ${ }^{6}$, Eduardo Schlindwein ${ }^{7}$, Ian Leipnitz ${ }^{8}$, Mário Henrique Mattos Meine ${ }^{9}$, Alfeu Fleck Jr. ${ }^{10}$, Ricardo Hoppen ${ }^{11}$, Guillermo Kiss ${ }^{12}$, Guido Pio Cracco Cantisani ${ }^{13}$
\end{abstract}

1. Study developed at the Post-Graduation Program of Surgery, Federal University of Rio Grande do Sul (UFRGS) and Hospital Dom Vicente Scherer, Porto Alegre, Brazil.

2. MD, Master of Surgery. Post-Grasduation Program of Surgery, UFRGS, Porto Alegre, Brazil.

3. MD, PHD, Associate Professor. Department of Morphological Sciences and Surgical Post-Graduation Program, UFRGS, Porto Alegre,Brazil.

4. MD, PhD. Post-Graduation Program of Surgery, UFRGS, Porto Alegre, Brazil.

5. MD, Full professor. Department of Gastroenterology, Federal Medicine Foundation (FFFCMPA), Porto Alegre, Brazil..

6. MD, Master of Gastroenterology. Department of Gastroenterology, FFFCMPA, Porto Alegre, Brazil.

7. MD, General Surgeon, Porto Alegre, Brazil.

8. MD, General Surgeon, Porto Alegre, Brazil.

9. MD, Master of Surgery. Post-Graduation Program of Surgery, UFRGS, Porto Alegre, Brazil.

10. MD, Master of Gastroenterology, Porto Alegre, Brazil.

11. MD, Master of Surgery. Post-Graduation Program of Surgery, UFRGS, Porto Alegre, Brazil.

12. MD, Fellow Master. Post-Graduation Program of Surgery, UFRGS, Porto Alegre, Brazil.

13. MD. Full Professor. Department of Surgery, UFRGS, Porto Alegre, Brazil.

\begin{abstract}
Purpose: The oxidative stress is an important mechanism responsible for dysfunction after orthotopic liver transplantation (OLT). Glutathione (GSH) low levels after cold storage render the grafts vulnerable to reperfusion injury. Aim of this study was to evaluate GSH and oxidized glutathione (GSSG) liver concentrations, the hepatocellular injury and function in optimal and suboptimal grafts after human OLT. Methods: Liver biopsies were taken in 33 patients before the implant and two hours after reperfusion, allowing determination of GSH, GSSG and oxidative stress ratio (GSH/GSSG). Serum transaminases, prothrombin activity (PT) and factor V were measured to evaluate injury and function respectively. Histopathological injury was analyzed by an index of five parameters. Results: There was a decrease in GSH (p<0.01) after reperfusion $(0.323 \pm 0.062 \mathrm{imol} / \mathrm{g}$ to $0.095 \pm 0.01 \mathrm{imol} / \mathrm{g}$ and $0.371 \pm 0.052 \mathrm{ìmol} / \mathrm{g}$ to $0.183 \pm 0.046 \mathrm{immol} / \mathrm{g})$ in suboptimal and optimal groups, respectively. An increase of GSSG ( $\mathrm{p}<0.05)$ occurred after reperfusion $(0.172 \pm 0.038$ ìmol/g to $0.278 \pm 0.077$ ìmol/g and $0.229 \pm 0.048 \mathrm{ìmol} / \mathrm{g}$ to $0.356 \pm 0.105 \mathrm{ìmol} / \mathrm{g}$ ) in suboptimal and optimal groups, respectively. A decrease ( $<<0.01$ ) occurred in the GSH/GSSG ratio after reperfusion ( $2.23 \pm 0.31$ to $0.482 \pm 0.042$ and $2.47 \pm 0.32$ to $0.593 \pm 0.068$ ) in suboptimal and optimal groups, respectively. Histopathological injury scores were higher $(\mathrm{p}<0.05)$ in the suboptimal group than in optimal (6.46 \pm 0.4 vs. $5.39 \pm 1.1)$ and showed correlation with PT and factor V in the optimal group ( $<<0.05)$. Multivariate analysis pointed steatosis as an independent risk factor to histopathological injury $(\mathrm{p}<0.05)$. Conclusion: There was a significant GSH depletion and GSSG formation after cold storage and reperfusion due to a similar oxidative stress in optimal and suboptimal grafts, but these levels were not related to graft viability.
\end{abstract}

Key words: Liver Transplantation. Oxidative Stress. Glutathione.

\section{RESUMO}

Objetivo: O estresse oxidativo é um importante mecanismo responsável pela disfunção dos enxertos após transplante de fígado (TF). Sabe-se que níveis baixos de Glutationa reduzida (GSH) deixam os enxertos vulneráveis aos danos de reperfusão. O objetivo deste estudo foi avaliar as concentrações de GSH e da Glutationa oxidada (GSSG), os danos hepatocelulares e a função em enxertos ótimos e subótimos após TF. Métodos: Foram realizadas biópsias em 33 pacientes imediatamente antes do implante e duas horas após a reperfusão, permitindo a determinação do GSH, GSSG e o cálculo do índice de stress oxidativo (GSH/GSSG). Foram medidas as transaminases hepáticas e as atividades da Protrombina (TP) e do Fator V para avaliação dos danos hepatocelulares e da função do enxerto, respectivamente. O dano histopatológico foi avaliado através de um índice de cinco parâmetros. Resultados: Houve uma diminuição nos níveis de GSH (p<0.01) $0.323 \pm 0.062$ ìmol/g to $0.095 \pm 0.01 \mathrm{ìmol} / g$ and $0.371 \pm 0.052 \mathrm{ìmol} / g$ to $0.183 \pm 0.046 \mathrm{ìmol} / g)$ e aumento nos níveis de GSSG (0.172 \pm 0.038 ìmol/g to $0.278 \pm 0.077 \mathrm{ìmol} / g$ and $0.229 \pm 0.048 \mathrm{ìmol} / \mathrm{g}$ to $0.356 \pm 0.105 \mathrm{ìmol} / \mathrm{g})(\mathrm{p}<0.05)$. Houve diminuição do GSH/GSSG ( $2.23 \pm 0.31$ to $0.482 \pm 0.042$ and $2.47 \pm 0.32$ to $0.593 \pm 0.068)$. Nenhuma diferença entre os grupos ótimo e subótimo foi vista 
após duas horas de reperfusão. Os escores de danos histopatológicos foram maiores no grupo subótimo (6.46 \pm 0.4 vs. $5.39 \pm 1.1)(\mathrm{p}<0.05)$ e mostraram correlação com o TP e fator V no grupo Ótimo $(\mathrm{p}<0.05)$. A análise multivariada apontou a esteatose como um fator de risco independente para a ocorrência de danos histopatológicos ( $<<0.05)$. Conclusão: Houve uma significativa depleção de GSH e formação de GSSG após a preservação em solução devido a um intenso estresse oxidativo nos enxertos ótimos e subótimos, porém estes níveis não se correlacionaram com a viabilidade dos enxertos.

Descritores: Transplante de Fígado. Estresse Oxidativo. Glutationa.

\section{Introduction}

Selection of liver donors can be a dilemma due to the combination of major risk factors as severe fatty infiltration, advanced donor age, longer ICU stay, hypernatremia, hemodynamic instability and extended cold ischemia time. These major risk factors and their combinations have been associated with a significant oxidative stress, severe injury, initial poor function, biliary complications and decrease in graft survival after OLT ${ }^{1,2}$. A major source of graft injury and dysfunction results from the overgeneration of ROS at the initial reperfusion by endothelial and Kupffer cells. ROS can activate redox-sensitive transcription factors, proinflammatory genes, proteases and contribute to the perfusion failure ${ }^{3,4}$. Their harmful effects are neutralized by antioxidant mechanisms, including the actions of GSH. Experimental studies have indicated that liver GSH is depleted after extended periods of cold storage ${ }^{5}$. Some reports suggest replenish GSH as preconditioning to improve graft function ${ }^{3,6}$. However, there is scarce information about GSH and GSSG liver concentrations after cold storage and reperfusion in clinical OLT. Moreover, only few reports have correlated donor risk factors with histopathological reperfusion injury found in the liver tissue ${ }^{7,8}$. The objectives were to evaluate GSH and GSSG liver concentrations after cold storage and reperfusion in optimal and suboptimal grafts and also the initial histopathological injury and function of the grafts.

\section{Methods}

The study protocol was submitted and approved by the Ethical Committee from Post Graduation Course of the Universidade Federal do Rio Grande do Sul. An informed consent to tissue and data collection was obtained from the donor family and from the recipient.

\section{Donors}

Thirty-three donors were accepted and assigned to Suboptimal (3 or more risk factors) or Optimal (less than 3 risk factors) groups according to presence or absence of risk factors observed in Table 1. 1,2

Suspicious viral or bacterial infection diagnosed within the graft by biopsy, and donors with HCV positive antibodies presenting chronic hepatitis were discharged. Livers were harvested using UW solution, two liters in aorta and two liters in portal vein. ABO compatibility was necessary to OLT.
TABLE 1 - Donor risk criteria according to Suboptimal and Optimal groups. Criteria based on Briceño et al., ${ }^{1,2}$

\begin{tabular}{lll}
\hline Donor risk factors & Suboptimal (I) & Optimal(II) \\
\hline $\mathrm{N}=33(100 \%)$ & $\mathrm{N}=15(45.4 \%)$ & $\mathrm{N}=18(54.6 \%)$ \\
Age donor $>65$ & $0(0 \%)$ & $1(5.6 \%)$ \\
Prolonged ICU stay $^{\mathrm{a}}$ & $9(60 \%)$ & $5(27.8 \%)$ \\
High inotropics $^{\mathrm{b}}$ & $7(46.7 \%)$ & $6(33.3 \%)$ \\
Hypotension $^{\mathrm{c}}$ & $8(53.3 \%)$ & $3(16.7 \%)$ \\
Cardiac arrest $^{\text {Hypernatremiad }}$ & $4(26.7 \%)$ & $1(5.6 \%)$ \\
High transaminases $^{\mathrm{e}}$ & $2(13.3 \%)$ & $3(16.7 \%)$ \\
Moderate to severe $^{\mathrm{f}}$ & $3(20 \%)$ & $1(5.6 \%)$ \\
steatosis $^{\mathrm{f}}$ & $4(26.7 \%)$ & $1(5,6 \%)$ \\
Hypoxemia $^{\mathrm{g}}$ & $0(0 \%)$ & $0(0 \%)$ \\
Alcoholism $_{\text {Drug addiction }}$ & $1(6.7 \%)$ & $1(5.6 \%)$ \\
Infection $^{\mathrm{h}}$ & $1(6.7 \%)$ & $1(5.6 \%)$ \\
Extended cold storage $^{\mathrm{i}}$ & $8(53.3 \%)$ & $4(21.1 \%)$ \\
\hline
\end{tabular}

a More than 3 days, ${ }^{b}$ Dopamine $>10 \mu \mathrm{g} / \mathrm{kg} / \mathrm{min}$, noradrenaline $>0.3$ $\mu \mathrm{g} / \mathrm{kg} / \mathrm{min}$ or concomitant use of two inotropics, c Systolic BP $<90$ $\mathrm{mm} \mathrm{Hg}$ in the last 2 hours, ${ }^{\mathrm{d}}$ Peak plasmatic sodium $>170 \mathrm{meq} / \mathrm{L}$, ${ }^{\mathrm{e}} \mathrm{At}$ least twice normal values, ${ }^{\mathrm{f}}$ more than $30 \%$, ${ }^{\mathrm{g}} \mathrm{PO} 2<70 \mathrm{~mm} \mathrm{Hg}$, ${ }^{\mathrm{h}}$ Positive cultures, fever and definitive foci, ${ }^{\mathrm{i}}$ More than 14 hours.

\section{Recipients}

OLT was performed in 33 recipients using the piggyback technique. Choledococholedocostomy without external biliary drainage was performed in 31 patients. A Roux-en-Y anastomosis was performed in 2 patients due to biliary common duct size mismatch. Methylprednisolone ${ }^{\circledR}$, (Roche, São Paulo, Brazil), 500 mg intraoperatively, followed tapering schedule from 200mg to 20mg in the first 6 days and FK 506 ${ }^{\circledR}$, (Jansen-Cilag, Dublin, Ireland), 0,1 mg/Kg divided in two doses were used as immunosuppressive therapy. Following transplantation all patients were monitored for the development of allograft dysfunction with standard liver tests, including serum transaminases (ALT, AST), PT and factor V. Peaks of AST levels above $1500 \mathrm{U} / \mathrm{L}$ associated with PT below 50\% at the end of fifth day were considered signs of graft dysfunction.

\section{Procurement of liver tissue}

Two biopsies were taken from the left lobe at different times: End of cold storage and two hours after portal 
reperfusion. Liver samples were immediately frozen in liquid nitrogen and stored at $-80^{\circ} \mathrm{C}$. Additionally, a fragment of the reperfusion sample was retrieved and stained with hematoxylin-eosin (HE).

\section{Determination of GSH, GSSG and GSH/GSSG}

Two aliquots of each liver biopsy were homogenized with perchloric acid and centrifuged at $15000 \mathrm{~g}$ for $1 \mathrm{~min}$ at $4^{\circ} \mathrm{C}$. To the supernatant was added 2-nitrobenzoic acid (DNTB). The GSH was oxidized by the DNTB to produce GSSG and nitrobenzoic acid (NTB). The GSSG was reduced de novo to GSH by NADPH in a reaction catalyzed by the glutathione disulfide redutase. A cycle between GSH and
GSSG was created. The rate of NTB formation is proportional to GSH and GSSG concentrations ${ }^{9}$. The final value considered to analyses was a mean of the two quotes. The oxidative stress index was calculated by GSH/GSSG ratio.

\section{Histopathological Injury Score (HIS)}

One pathologist in a blinded fashion assessed HE sections looking at five tissue injury parameters. The histopathological features examined were sinusoidal congestion, hydropic degeneration (ballooning), hepatocellular necrosis, neutrophilic infiltrates and steatosis. All ranged from score 0 until 4, except steatosis, which ranged from 0 until 3. Chart 1.

CHART 1 - Classification of reperfusion injury

\begin{tabular}{llllll}
\hline Degree & Sinusoidal congestion & $\begin{array}{l}\text { Hydropic } \\
\text { degeneration }\end{array}$ & Necrosis & $\begin{array}{l}\text { Neutrophilic } \\
\text { infiltration }\end{array}$ & Steatosis \\
\hline $\mathbf{0}$ & Absent & Absent & Absent & Absent & Absent \\
$\mathbf{1}$ & CVa dilatation & Minimal & Focal & Minimal & Mild $(<30 \%)$ \\
$\mathbf{2}$ & CV and Sb dilatation in a few zone 3 & Mild & Confluent & Mild & Moderate $(<60 \%)$ \\
$\mathbf{3}$ & CV and S dilatation in most of zone & Moderate & Zonal & Moderate & Severe $(>60 \%)$ \\
$\mathbf{4}$ & CV and S dilatation in zones 2 and & Severe & Generalize & Severe & \\
\hline
\end{tabular}

${ }^{\text {a }}$ Centrilobular vein

b Sinusoids

The sum of histopathological injury score (HIS) was recorded for each specimen allowing further comparison with donor risk factors, GSH, GSSG GSH/GSSG and liver tests.

\section{Statistics}

Comparison between the groups was performed applying the Mann Whitney U-test. Comparison of GSH, GSSG levels and GSH/GSSG inside the groups was done by Wilcoxon signed rank test (T). A bivariate analysis was performed between donor risk factors, GSH, GSSG and GSH/GSSG with HIS and liver tests by Spearman correlation index. Multivariate analysis was performed to identify independent donor risk factors. The level of significance was assigned to 0.05 .

\section{Results}

\section{Characteristics of donors and recipients}

Mean donors age was identical in the Suboptimal and Optimal groups (37.9 years). Seventeen (51.5\%) were women and sixteen (49.5\%) were men. Mean ICU stay was 5.6 days in the Suboptimal group and 3.58 days in the Optimal group. Only two donors (6.1\%) were not under inotropics during the harvesting. The causes of brain death were cranioencephalic trauma in 19 (57.6\%), hemorrhage in 12 (36.4\%) and cardiac arrhythmia and hypoxemia in 1 each (3 $\%)$. Table 1 shows the risk criteria distribution, which determined inclusion to each group.

The mean \pm SEM donor risk factors in Suboptimal and
Optimal groups were respectively $4 \pm 0.26$ and $1.26 \pm 0.17$. The recipients were chosen according to the unique list adopted by governmental law. Mean age was 48.8 years (18-68) and twenty-six were male (75.8\%). Child-Pugh scores at time of transplant were respectively in Suboptimal and Optimal groups as follows: $\mathrm{A}$ in 13.3\% and $33.3 \%$, B in 60\% and $33.3 \%$ and $\mathrm{C}$ in $26.7 \%$ and $33.3 \%$. The main indication for transplantation was cirrhosis post hepatitis C in $42.4 \%$, post hepatitis $\mathrm{C}$ plus alcohol in $12.1 \%$, alcoholic isolated in $12.1 \%$. Cirrhosis post hepatitis $\mathrm{B}$, hemochromatosis, criptogenic, familial amiloidosis and autoimmune were seen in $6.03 \%$ each. Fulminant hepatitis was seen in 3.03\%. In four cases a coexistent hepatocellular carcinoma was diagnosed. Total and cold ischemia times were $759 \pm 51$ and $712 \pm 49$ minutes in Suboptimal group and $662 \pm 28$ and 610 \pm 27 minutes in the Optimal group, respectively.

\section{Liver GSH and GSSG analysis}

At the end of cold storage, mean GSH tissue concentrations were $0.323 \pm 0.062 \mathrm{imol} / \mathrm{g}$ and $0.371 \pm 0.052$ ìmol/g in Suboptimal and Optimal groups, respectively. After 2 hours of reperfusion there was a significant decrease to $0.095 \pm 0.01 \mathrm{imol} / \mathrm{g}$ and $0.183 \pm 0.046 \mathrm{ìmol} / \mathrm{g}$ in Suboptimal and Optimal groups $(\mathrm{p}<0.01)$. No significant differences were detected between the groups in GSH levels after cold storage and reperfusion. In order to determine whether this decline in GSH was due to its oxidation caused by oxidative stress, GSSG concentrations were determined in the same samples. At the end of cold storage, mean GSSG liver 
concentrations were $0.172 \pm 0.038 \mathrm{ìmol} / \mathrm{g}$ and $0.229 \pm 0.048$ ìmol/g in Suboptimal and Optimal groups, respectively. After 2 hours of reperfusion there was a significant increase to $0.278 \pm 0.077 \mathrm{imol} / \mathrm{g}$ in Suboptimal and $0.356 \pm 0.105 \mathrm{ìmol} / \mathrm{g}$ in Optimal group $(\mathrm{p}<0.05)$, but without significant differences between the groups. The Figures 1 and 2 show the distribution of GSH and GSSG between the groups.

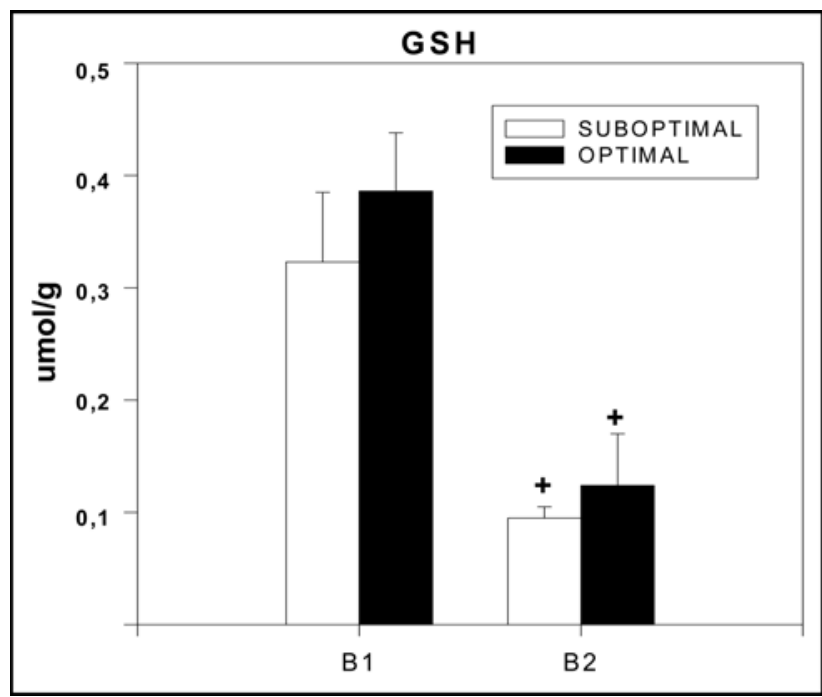

FIGURE 1 - Liver tissue reduced glutathione (GSH) levels of 33 liver transplant patients in Suboptimal (white) an Optimal (black) groups in different times (B1: end of cold storage; B2: 2 hours after reperfusion). $+\mathrm{p}<0.01$ (Wilcoxon $\mathrm{T}$ test). Results are means \pm SEM.

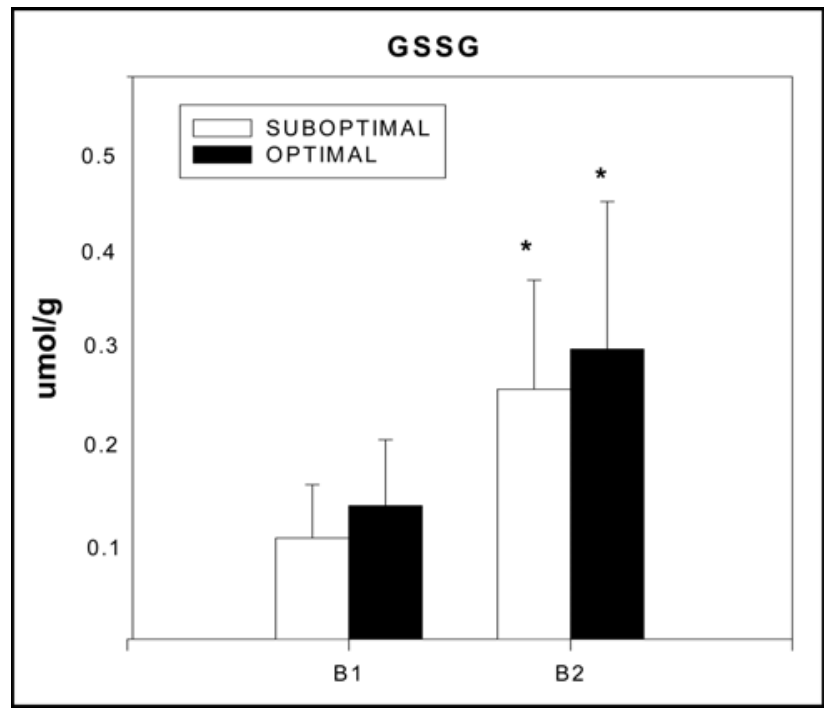

FIGURE 2 - Liver tissue oxidized glutathione (GSSG) levels of 33 liver transplant patients in Suboptimal (white) and Optimal (black) groups in different times. (B1: end of cold storage; B2: two hours after reperfusion) ${ }^{*} \mathrm{p}<0.05$ (Wilcoxon $\mathrm{T}$ test). Results are means \pm SEM.
At the end of cold storage the GSH/GSSG ratio was $2.23 \pm 0.312$ and $2.47 \pm 0.32$ in Suboptimal and Optimal groups, respectively. Two hours after reperfusion, there was a significant decrease in GSH/GSSG ratio to $0.482 \pm 0.042$ and $0.593 \pm 0.068$ in Suboptimal and Optimal groups respectively $(\mathrm{p}<0.01)$. Once more, no significant difference between the groups was observed in GSH/GSSG ratio before and after reperfusion. The oxidative stress of each patient is seen in Figure 3.

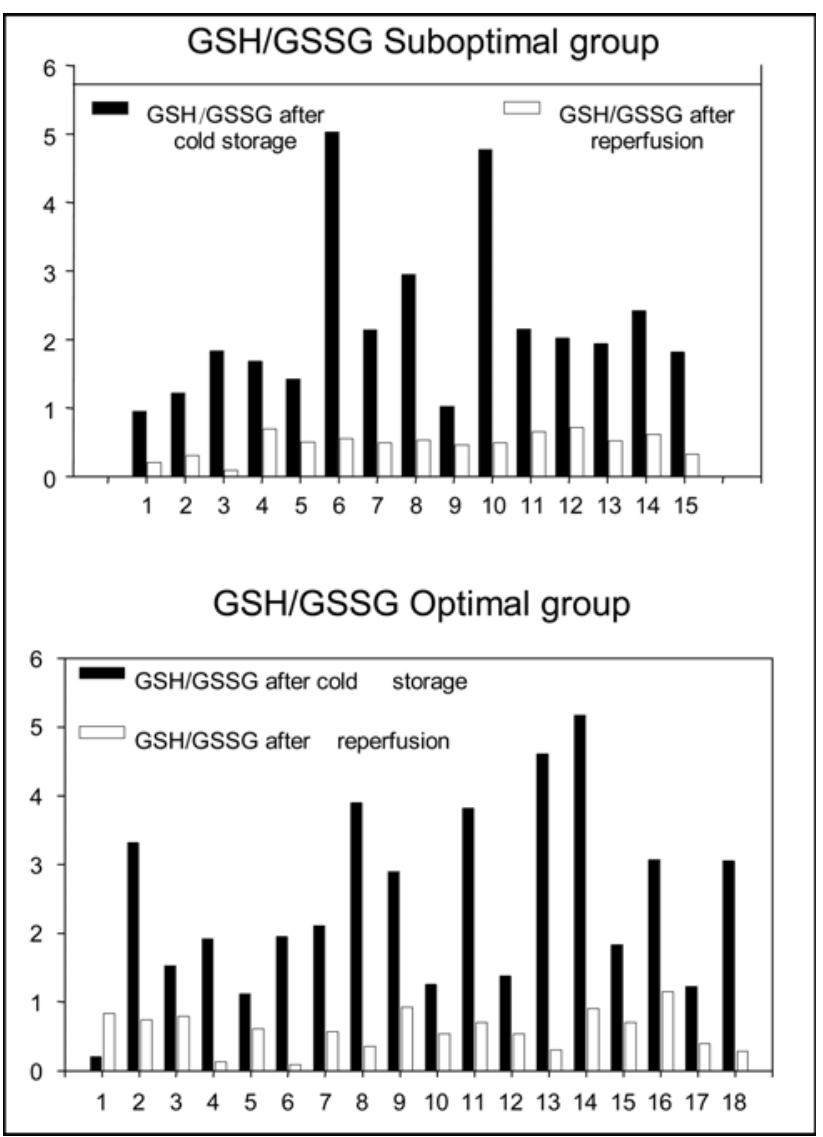

FIGURE 3 - Oxidative stress index (GSH/GSSG) of each case in Suboptimal and Optimal groups. There was a significant decrease in the means of both groups $(\mathrm{p}<0.01)$ (Wilcoxon T test).

\section{Histopathological Injury Score (HIS)}

There was a significant difference in the HIS at the end of two hours of reperfusion between the groups. Suboptimal group HIS was $6.46 \pm 0.4$ and Optimal group HIS was $5.39 \pm$ $1.1(\mathrm{p}<0.05)$.

\section{Hepatocellular injury}

Transaminases serum levels showed an abrupt elevation after the initial reperfusion with progressive decline in the subsequent five days after the transplant. ALT mean levels ranged between first and fifth days from $847 \pm 261 \mathrm{U} / \mathrm{L}$ and $505 \pm 151 \mathrm{U} / \mathrm{L}$ in Suboptimal group and 
from $585 \pm 114 \mathrm{U} / \mathrm{L}$ and $332 \pm 73 \mathrm{U} / \mathrm{L}$ in the Optimal group. AST mean activities between first and fifth day were $1423 \pm$ $505 \mathrm{U} / \mathrm{L}$ and $298 \pm 94 \mathrm{U} / \mathrm{L}$ in Suboptimal group and $960 \pm 230$ $\mathrm{U} / \mathrm{L}$ and $139 \pm 36 \mathrm{U} / \mathrm{L}$ in Optimal group. There was no significant difference between the groups.

\section{Hepatic function}

The hepatic function had a progressive recovery in the subsequent days after transplantation. Prothrombin mean activity ranged between $38.8 \% \pm 2.9 \%$ and $57.6 \% \pm$ $3.9 \%$ in the Suboptimal group between first and fifth days $(\mathrm{p}<0.05)$. In the Optimal group, PT ranged between $37 \% \pm$ $2.4 \%$ and $58.7 \% \pm 4.4 \%$ between the first and fifth days $(\mathrm{p}<$ 0.05). Factor $\mathrm{V}$ means increased from $33.6 \% \pm 6.8 \%$ to $77.3 \%$ $\pm 9.2 \%$ in the Suboptimal group $(\mathrm{p}<0.01)$, and from $28.7 \% \pm$ $2.9 \%$ to $72.6 \% \pm 6.5 \%$ between first and third days in the Optimal group $(\mathrm{p}<0.01)$. For both, no differences were demonstrated between the groups.

\section{Correlations}

Bivariate analysis was performed between donor risk factors and liver function tests with HIS. The most significant findings were a correlation between HIS and donor age in Suboptimal group $(\mathrm{p}<0.05)$, but not in Optimal. The PT and FV had a significant negative correlation with HIS in the Optimal group $(\mathrm{p}<0.05)$, but only PT presented this correlation when both groups were evaluated together $(p<0.05)$. The presence of moderate to severe steatosis showed significant positive correlation with HIS in Suboptimal and Total group $(\mathrm{p}<0.05)$. The multivariate analysis showed that only donor steatosis was an independent factor increasing histopathological injury scores $(\mathrm{p}<0.05)$.

\section{Discussion}

\section{Oxidative stress and reperfusion injury}

We evaluated GSH and GSSG concentrations in liver tissue samples of optimal and suboptimal donors as potential markers of oxidative stress in liver transplant recipients ${ }^{6}$. We have demonstrated significant changes in GSH and GSSG concentrations from the end of cold storage until 2 hours after implant suggesting that an intense oxidative stress takes place at the initial phase of the reperfusion. Thus, significant decrease in the cell viability occurred after the reperfusion in both groups, since GSH/GSSG ratio showed a significant decrease after two hours of reoxygenation. Some authors have advocated the use of intravenous GSH and other antioxidants during the liver transplant as a promise drugs and found a significant reduction of injury in the hepatocytes, endothelial cells and microcirculation ${ }^{3,6,10-12}$.

Despite most studies points the more pronounced oxidative stress occurring at extracellular space after the reperfusion ${ }^{13,19}$, we found also very low cytosolic levels of GSH at the end of cold storage and insignificant levels after two hours of reperfusion. These findings probably are the effect of the high consumption of the GSH during the cold storage and the translocation of the GSH to extracellular compartment to detoxify ROS released by the Kupffer cells after the reperfusion. These behavior was as intense in optimal as in suboptimal grafts, but suboptimal grafts developed significantly more damage at the initial reperfusion. Since the cell injury at the first phase of the reperfusion is mediated mainly by ROS, the suboptimal grafts were more susceptible to injury than optimal grafts, but this effect was not related to GSH concentrations.

In comparison with the physiologic levels of $\mathrm{GSH}$ within hepatocytes (5-10 mmol/g), the decrease of GSH liver concentrations in the current study was very marked. This finding is evidence that cold storage represents a critical interval to GSH consumption and the GSH present in the preservation solutions does not prevent the GSH depletion, as previously demonstrated ${ }^{14,20}$. An additional GSH consumption occurred at the first hours of reperfusion. A significant number of the grafts were almost completely depleted from their GSH antioxidant capacity after only 2 hours. Experimental reports have shown that GSH depletion accentuates hepatocellular fluid accumulation after ischemia-reperfusion and compromise the high-energy phosphate metabolism ${ }^{15}$. In line with these findings, cell ballooning was also a prominent feature responsible for the hepatocellular injury scores.

Usually GSSG represents only 1 to $10 \%$ of the total liver glutathione $^{3}$. In the present study, liver GSSG at the end of the cold storage accounted almost $50 \%$ of total glutathione, suggesting that there was a significant intracellular oxidative stress during the cold storage. Possibly, the poor energetic status of the cells during the cold storage was unable to convert a single molecule of GSSG in two GSH molecules to establish the normal ratio between GSH and GSSG ${ }^{16,20}$. There was also an additional and significant increase in the GSSG concentrations after two hours of reperfusion, reflecting the burst of ROS released after the initial reperfusion mediated by Kupffer cells. We did not take a donor biopsy to evaluate GSH and GSSG liver concentrations. Although these levels might contribute to understand the behavior of GSH and GSSG, evidences show that a significant GSH consumption occurs mainly during cold storage and reperfusion ${ }^{14}$.

Our results contrast partially with Ardite et al, which reported for the first time GSH and GSSG concentrations in liver tissue samples in clinical liver transplantation ${ }^{7}$. Very likely, short cold storage times observed in their study (mean 310 minutes) were not enough to produce GSH depletion. In contrast, the current study had higher mean cold storage time (720 minutes), and this prolonged cold ischemia could be one reason to induce GSH consumption. Moreover, the time when biopsies were taken may play a pivotal role. Whereas in our study the biopsies were taken after 2 hours of reperfusion, Ardite et al. obtained most of their samples after 5 and 10 minutes of reperfusion. Evidences suggest that GSH do not suffer significant reduction after 30 minutes of reperfusion ${ }^{17}$. However, in the current study, despite the significant GSH depletion and GSSG consumption, there was no correlation between liver injury and GSH and GSSH concentrations, a finding similar with those authors. 
Moreover, the results were similar in optimal and suboptimal grafts. Thus, the GSH depletion after cold storage and initial reperfusion did not predict graft viability. Other conditions, such as steatosis possibly were responsible for the high injury indexes in the suboptimal grafts.

\section{Integrity and function}

It has been demonstrated that patient's survival after OLT is affected only with extreme AST elevation (> 5000 U/ $\mathrm{L}$ ) in conjunction with other function parameters ${ }^{21}$. In agreement with these reports, we did not observe correlation between transaminases and histopathological injury (data not shown). In contrast, there was significant correlation between PT and factor V with HIS. Thus, PT activity and factor $\mathrm{V}$ production were more reliable parameters of the graft reperfusion injury in this study,

Only 4 grafts showed dysfunction (12,1\%) according to the selected criteria. Although dysfunction rates in the Suboptimal group were higher (20\%) than in Optimal group $(5,6 \%)$, the reduced number of dysfunctional grafts in our study did not allow definitive conclusions. No case of severe injury was found in our study. This finding contrasts with Briceño et al ${ }^{2}$. These authors found unacceptable reperfusion injury and higher dysfunction rates when organs from donors with more than 3 risk criteria were transplanted ${ }^{2}$. The follow-up of one year showed a patient and graft survival of $97 \%$.

\section{Effect of donor risk factors on reperfusion injury}

We observed correlation between moderate and severe steatosis with reperfusion damage as previously reported $2,15,18$. The higher rate of dysfunction in the Suboptimal group was probably effect of steatosis, since almost all moderate to severe steatotic grafts were allocated to this group. The multivariate analysis pointed moderate to severe steatosis as an independent risk factor related to reperfusion injury. In the other side, extended preservation is strongly correlated with dysfunction and a cold storage longer than 14 hours is associated with a two-fold preservation injury ${ }^{1}$. However, there were no significant differences in the mean cold storage time when both groups were compared. Three grafts had more than 14 hours of cold ischemia in the Suboptimal group, but none of them presented severe injury. Thus, cold ischemia times practiced in this study was not a significant feature involved in the higher histopathological scores observed in the Suboptimal group.

Necrosis and neutrophilic infiltrates have been considered useful parameters to predict dysfunction and biliary complications after liver transplantation ${ }^{8,15}$. As we demonstrate, correlations between HIS with PT and factor V suggest that biopsies could provide a foresight of initial graft function and a better clinical support to avoid early failures.

\section{Conclusion}

Our data indicate that there is a significant GSH depletion and GSSG consumption during cold storage and initial reperfusion, but the oxidative stress was not directly related to liver injury. Moderate to severe steatosis was an independent factor enhancing histopathological injury scores.

\section{References}

1. Briceño J, López-Cillero P, Rufián S. Impact of marginal quality donors on the outcome of liver transplantation. Transplant Proc. 1997; 29: 477-80.

2. Briceño J, Marchal T, Padillo J, Solórzano G, Pera C. Influence of marginal donors on liver preservation injury. Transplantation. 2002; 74: 522-6.

3. Bilzer M, Paumgrtner G, Gerbes A. Glutathione protects the rat liver against reperfusion injury after hypothermic preservation, Gastroenterology. 1999; 117: 200-10.

4. Burke A, Fitzgerald G, Lucey M. A prospective analysis of oxidative stress and liver transplantation. Transplantation. 2002; 74: 217-21.

5. Mamprím E, Guibert EE, Rodríguez J. Glutathione content during the rinsing and rewarming process of rat hepatocytes in University of Wisconsin Solution. Cryobiology. 2000; 40: 270-6.

6. Schauer R, Kalmuk S, Gerbes AL, Leiderer R, Meissner $\mathrm{H}$, Schildberg FW, Messmer K, Bilzer M. Intravenous administration of glutathione protects parenchymal and non-parenchymal liver cells against reperfusion injury following rat liver transplantation. World J Gastroenterol. 2004; 10: 864-70.

7. Ardite E, Ramos C, Rimola A, Grande A, Fernandéz-Checa JC. Hepatocellular oxidative stress and initial graft injury in human liver transplantation. J Hepatology. 1999; 31: 921-7.

8. Gaffey MJ, Boyd JC, Traweek ST. Predictive value of intraoperative biopsies and liver function tests for preservation injury in orthotopic liver transplantation. Hepatology. 1997; 25: 184 -9.

9. Teare JP, Punchard NA, Powell JJ, Lumb PJ, Mitchell WD, Thompson RPH. Automated spectrophotometric method for the determining oxidized and reduced glutathione in liver. Clin Chem. 1993; 39: 686-9.

10. Koeppel T, Lehmann T, Jochen C. Impact of $\mathrm{N}$ acetylcysteine on the hepatic microcirculation after orthotopic liver transplantation. Transplantation. 1996; 61: 1397-400.

11. Dunne B, Davenport M, Williams R, Tredger JM. Evidence that s-adenosylmethionine and $\mathrm{N}$ acetylsysteine reduce injury from sequential cold and warm ischemia in the isolated perfused rat liver. Transplantation. 1994; 57: 1161-8.

12. Thies JC, Koeppel TA, Lehmann T, Schemmer P, Otto G, Post S. Efficacy of $\mathrm{N}$-acetylcysteine as a hepatoprotective agent in liver transplantation: an experimental study. Transplant Proc. 1997; 29: 1326-7.

13. Jaeschke H, Farhood A. Neutrophil and kupffer cellsinduced oxidant stress and ischemia-reperfusion in the rat liver. Am J Physiol. 1991; 260: 355-62. 
14. Yandza T, Msanika A, Huynh T, Lavoie JC, Champagne J, Lepage G, Chessex P. Glutathion intra-hépatique et stress oxydatif en transplantation du foie chez le cochon. Ann Chir. 1997; 51: 839-46.

15. Suzuki H, Robinson MK. Glutathione deficiency accentues hepatocellular fluid accumulation after ischemia-reperfusion. J Surg Res. 1994; 57: 632-9.

16. Grattagliano I, Vendemiale G, Lauterburg H. Reperfusion injury of the liver: role of mitochondria and protection by glutathione ester. J Surg Res. 1999; 86: 2-8.

17. Fujikawa M, Kamike W, Hatanaka K. Changes in biliary glutathione level during ischemia-reperfusion of rat liver. J Surg Res. 1994: 57: 569-73.

18. Busquets J, Serrano T, Figueras J. Influence of donor post reperfusion changes on graft evolution after liver transplant. Transplant Proc. 2002; 34: 252-3.
19. Biasi F, Bosco M, Chiappino I. Oxidative damage in human liver transplantation. Free Rad Biol Med. 1995; 19: 311-7.

20. Rodríguez JV, Mamprín M, Mediavilla M, Guibert E. Glutathione (GSH) movements during cold preservation of rat hepatocytes. Cryobiology. 1998; 36: 236-44.

21. Rosen HR, Martin P, Goss J. Significance of early aminotransferase elevation after liver transplantation. Transplantation. 1998; 65: 68-72.

\section{Acknowledgement}

The authors thank FAPERGS by partial financial supporting.

\section{Correspondence:}

Tomaz J. M. Grezzana

Rua Irmão José Otão, 170/406

90035-06 Porto Alegre-RS Brazil

Phone/Fax: (5551)3214-8211

tomgrez@uol.com.br
Conflict of interest: none

Financial source: FAPERGS

(Fundação de Apoio à Pesquisa do Estado do Rio Grande do Sul)

Received: January 10, 2006

Review: February 18, 2006

Accepted: March 21, 2006

\section{How to cite this article:}

Grezzana Filho TJM, Corso CO, Zanotelli ML, Marroni CA, Brandão ABM, Schlindwein E, Leipnitz I, Meine MHM, Fleck Jr A, Hoppen R, Kiss G, Cantisani GPC. Liver glutathione depletion after preservation and reperfusion in human liver transplantation. Acta Cir Bras. [serial on the Internet] 2006 July-Aug;21(4). Available from URL: $\underline{\text { http://www.scielo.br/acb }}$ 